\title{
TRADITIONAL KNOWLEDGE AND THE USES OF NATURAL RESOURCES BY THE RESETTLEMENT OF INDIGENOUS PEOPLE IN MALAYSIA
}

\author{
Muhammad Fuad Abdullah ${ }^{1^{*}}$, Azmah Othman ${ }^{2 *}$, Rohana Jani ${ }^{* * *}$, Candyrilla Vera \\ Bartholomew ${ }^{4}$, Elizabeth Pesiu ${ }^{5} \&$ Mohd Tajuddin Abdullah ${ }^{4}$ \\ ( ${ }^{*}$ First author, ${ }^{* *}$ Corresponding author) \\ ${ }^{1}$ Institute for Advance Studies, University of Malaya, Kuala Lumpur, Malaysia. \\ ${ }^{2 * *}$ Department of Development Studies, Faculty of Economics and Administration, University \\ of Malaya, Kuala Lumpur, Malaysia. \\ ${ }^{3 * *}$ Department of Applied Statistics, Faculty of Economics and Administration, University of \\ Malaya, Kuala Lumpur, Malaysia. \\ ${ }^{4}$ Institute of Tropical Biodiversity and Sustainable Development, Universiti Malaysia \\ Terengganu, Kuala Terengganu, Malaysia. \\ ${ }^{5}$ Faculty of Science and Marine Environment, Universiti Malaysia Terengganu, \\ Kuala Terengganu, Malaysia. \\ (fuad87@um.edu.my, g3azmah@um.edu.my, rohanaj@um.edu.my, candyrilla92@gmail.com, \\ elizabethpesiu@yahoo.com, mohd.tajuddin@umt.edu.my) \\ DOI: https://doi.org/10.22452/jati.vol25no1.9
}

\begin{abstract}
Indigenous people are generally descended from original inhabitants of the land in which they inhabit and as such have a historical relationship with their land. Nowadays, most of the Orang Asli have been resettled to a village provided by the government. Nevertheless, they are still carrying out their traditional lifestyle, such as hunting and gathering forest product. Over many generations, they have developed a holistic ancestral traditional knowledge of their lands, natural resources and environment, which plays an important role in their livelihood and well-being. Documentation of traditional knowledge on natural resources by the native people in Malaysia is still far from complete. Thus, the objective of this study is to document the traditional knowledge and natural resources used by the Orang Asli in their livelihoods. This study adopts a qualitative approach through exploratory study whereby the study was carried out at the Orang Asli resettlement villages in the state of Terengganu, Malaysia. Data was obtained from the tribal elders who served as informants using indepth interviews and field observations. The results show that two plant species mainly relied on the Orang Asli for their economic activity, including agarwood
\end{abstract}


and rattan. Besides, there are 34 species of plants and herbs, 31 species of animals and 31 species of fishes that commonly utilised by the Orang Asli in Terengganu, Malaysia. Interestingly, they still using conventional methods and equipment to harvest natural resources needed. Therefore, the government have to raise the importance of traditional knowledge and preserve the natural resources by adapting them into the formal education system for the sake of the new generation of Orang Asli. Besides, the data collected will be useful for researchers, JAKOA and policymakers to improve the lifestyle and well-being of the Orang Asli.

Keywords: indigenous people, ecological knowledge, Semaq Beri, Kenyir Lake, Terengganu

\section{Introduction and Background}

The indigenous people are significant and constitute vital portions of humanity. To date, there is no clear definition of indigenous people internationally. However, the most common description is from Jose R. Martinez Cobo who defined the indigenous people as a "community, peoples and nations which are having a historical continuity with pre-invasion and pre-colonial societies now prevailing on those territories. At present they form non-dominant sectors of society. They are determined to preserve, develop and transmit to future generations their ancestral territories and their ethnic identity, as the basis of their continued existence as people are following their cultural patterns, social institutions and legal system" (Kardooni, Kari, Yahaya, \& Yusup, 2014).

There are approximately more than 370 million indigenous people spread across 90 countries all over the world. Although they are just present a small portion of the world population (up to 5 percent) yet, they contribute about 15 percent of the extreme poverty and hunger. The outnumbered of indigenous people who are still practising unique social, traditions and cultural, retaining backward economic and political characteristics which are distinct from the mainstream societies (United Nations, 2012). Even though indigenous people occupy and use quarterly of the world's surface area, they also safeguard $80 \%$ of the biodiversity. They hold vital ancestral knowledge and expertise on how to adapt, mitigate and reduce climate and disaster risk (World Bank, 2019). Most of the land given to the indigenous people is under indigenous customary ownership and many governments yet recognise only a fraction of this land as formally or legally belonging to indigenous people. The government has the right to take back the property in the name of development. In other words, the indigenous never own the land permanently. Insecure land tenure has led to the 
conflict, environmental degradation and weak economic and social development. This threatens the cultural survival and vital knowledge system-both of which contribute to ecological integrity, biodiversity and environmental health upon which we all depend (Nor, 1991).

The indigenous people normally live deep in the forest where it is rich in biodiversity. Their resource management system that involved the intricate knowledge that gained over generations is known as traditional knowledge or indigenous knowledge, has been essential for the preservation of the resources in the traditional territory (Rosliza \& Muhamad, 2011). In fact, they are very survival as a human being who unfavourably depends only on their ability to creatively like off nature even as they help to conserve and sustain it. To ensure the community's culture survival and sustainability of their surrounding biodiversity, this kind of knowledge being passed down through generations. Traditional knowledge is unwritten and handed down orally from generation to generation. It is also transmitted and preserved in that way. Ironically, some of this indigenous or traditional knowledge is highly sacred and secret nature. Thus, some of them are extremely sensitive, penetrating, and culturally significant towards their traditional knowledge. It is because every indigenous tribal have their right to preserve their ancestral knowledge from any thread (Leake, 2007).

The maintenance and protection of indigenous traditional knowledge is crucial to preserve indigenous culture. Unfortunately, mainstream development, especially on land (logging, land degradation, urbanisation, modern agriculture and commercial plantation), have changed the indigenous social and economic background where it transforms the most of tropical forest differently (Chan, 2018). Since the indigenous people are not immune to this threat, there must be a wise step in documenting such traditional knowledge that practised by them as the basis to scientific research and to give some more understanding regarding the ecology system of the forest. As such, it is crucial to identify and document the natural resources used by the indigenous people before the knowledge has lost forever. Besides, this traditional knowledge will also help to ensure the conservation and sustainable use of these natural resources. Therefore, this study aims to document the utilisation of natural resources based on common traditional knowledge used by the indigenous people in Terengganu, Malaysia.

\section{Traditional Knowledge}

Traditional knowledge (TK) plays a vital role in daily lives not only for the indigenous community but also for the mainstream population. Although there is no clear definition at the international level, but still, it can be defined as 
knowledge, know-how, skill and practices developed, sustained and transmitted verbally through generation within a community, often forming part of its cultural or spiritual identity (Anyaoku, Nwafor-Orizu, \& Eneh, 2015). TK is a widely used term to define the local knowledge that is unique to a given culture or society comprehended as the conventional way of learning, especially among the marginalised people. TK refers to cumulative knowledge, know-how, practices, culture, heritage which is developed by specific community (usually marginalised group) based on historical interactions with the surrounding natural environment. These complex connotations representing complex culture embraced by language, naming, taxonomy system, natural resources usage, ritual, spiritual and worldviews and relations with the nature (Hussin, 2018, Permana, RCE, 1999). This statement is in line with United Nations claim that there are numerous definitions, terms and contexts used by academia and intergovernmental bodies referring to TK whereby it represents complex nature of societies and diversity of worldviews. Recently, the importance of TK has been recognised as a valuable advantage by biotechnology and bio-prospecting (Christen, 2015). It can be seen through the identification of plants and their byproducts with the pharmacological value, which could be utilised in the production of modern medicines. In fact, traditional medicine practices have remained an accessible and affordable way in curing the poor, marginalised community.

Ultimately, TK is a kind of life-long knowledge which passed through generation irrespective of background by integrating with the environment over time. It is also an experience based-knowledge which usually embraced by indigenous people to sustain their ancestral culture, natural resources and livelihood in ensuring the survival of the community. Like other indigenous people, the Orang Asli community in Malaysia also do not have any formal writing system to preserve their TK. However, it can be seen through their knowledge, skill and expertise about surrounding forest, the component of ecology, wildlife, culture, taboo and socioeconomic activity. Ironically, the value of TK inherited by the older is being diminished by various factors for instance religion, urbanisation, modernisation and also the loss of natural resources due to the rapid exploitation of forest in the name of development for commercial activities especially agricultural (Campbell, Ghazali, \& Suffian Sahuri, 2016).

\section{Natural Resources}

Natural resources are the possessions that are occurring in nature which can be used for economic production or consumption. These are fundamentally categorised into mineral, energy, soil, water and biological resources which are 
subjected to quantitative depletion through human use (Organisation for Economic Co-operation and Development, 2001). Natural resources also recognised as renewable and non-renewable resources. Non-renewable resources are resources that do not form naturally in the environment or have a prolonged formation rate such as fossil fuels. Meanwhile, renewable resources are replenished naturally such as sunlight, air and wind. They have a rapid reproduction rate which exceeds human consumption; thus, their quantity is not noticeably affected. However, some of them, for instance, the forest and wildlife have slower recovery rate yet, are vulnerable to depletion by over consumption. Thus, appropriate management on these kinds of natural resources is essential to ensure their sustainability.

Traditionally, indigenous people live by hunting and gatherer activities relied on natural resources for generations (Friedlander et al., 2016). Traditional culture usually encompasses the utilisation of natural resources. Besides, they play a vital role in their livelihood strategies and daily routine such as during hunting, fishing, planting, home building, handicraft making as well as in curing straightforward ailments. There were previous studies that conducted on the use of plants, animals and aquatic species by different indigenous community which shows the importance of these natural resources for them. In facts, it gives a clear picture of how close the indigenous community with the natural environment (Ter Steege et al., 2015). Therefore, any changes in the environment will affect people's livelihood strategies and vice versa. Modernisation and land development process mainly affect the symbiotic relationship between communities and nature. Thus, the Orang Asli community is no exception.

Mainstream development nowadays has made rapid changes toward the natural environment by boost up economics, political and cultural changes. Therefore, some of TK diminished from Orang Asli culture (Kalita et al., 2004). The Orang Asli traditional knowledge or sometimes interchangeable with traditional ecological and environmental knowledge is arguably one of the most critical aspects that distinguish Orang Asli management systems from the domain Western 'scientific' resource management models. The livelihoods of rural households depend on the accessibility of natural resources such as agriculture, livestock, poultry, fisheries and forest as well as the underlying environmental services that sustain these resources (Cheng et al., 2014). Several studies on the livelihood strategies of rural communities have also shown that the economic activities of the rural communities still rely heavily on natural resources. It is also observed that Orang Asli in Malaysia are still deprived and relying on natural resources for their core socioeconomics activities (Abdullah, Rohana, \& Abdullah, 2016). 


\section{Orang Asli Community in Malaysia}

As a country in Southeast Asia with the approximate population of 31 million people, $13.9 \%$ of the total population contributed by indigenous people (International Work Group for Indigenous Affairs, 2017). The indigenous people who occupy West Malaysia (known as Peninsular Malaysia) is the earliest community who live here. They are collectively known as 'Orang Asli' which is in Malay terms referring to 'original people' or 'first people' which represent around 178,000 people or $0.6 \%$ of the population in Peninsular Malaysia (Department of Orang Asli Affairs, 2011). Malaysia is a country with multiple ethnicities; among them Malay, Chinese and India are the prime populations while Orang Asli (Malaysian indigenous people) comprises only $1 \%$ of the population of Malaysia (Thevakumar et al., 2016). This minority group which have unique cultural heritage, religion, socio-economic, and beliefs compared to other races. They are often associated with the native habitats whose behavioural pattern is dependent on ancient culture and subsistent socio-economic living. There are 90 different groups of indigenous tribal in Malaysia where the Orang Asli can only be found in peninsular, while others reside in Sabah and Sarawak on the island of Borneo. Based on their geographical distribution, language, and morphological characteristics, Orang Asli are divided into three major tribes and 18 sub-tribes within the Negrito (Semang), Senoi and Proto-Malay (Aboriginal Malay) (Abdullah et al., 2016). However, they live in a heterogeneous setting because each sub-tribe has its own respective followed trait (Lambin, Wahab, Choo, Mustapha, \& Abdullah, 2018).

The Orang Asli is an aborigines minority group of people who live in a primitive environment with poor health and education services, lack of social development and is the financially disadvantaged community (Abdullah, Othman, Edo, \& Jani, 2019). They are culturally distinct societies. Most of them live far away from the mainstream community, somewhere in remote areas or deep into the forest surrounded by ample biodiversity (Endicott \& Dentan, 2004). Almost $60 \%$ of the Orang Asli people, live in the forest-fringe or rural areas, while $30 \%$ live in the forest interiors and the remote regions. Only 1\% of the Orang Asli community lives in the settlements or areas close to the urban centres.

The land where they live and get the natural resources as food are inextricably linked to their identities, cultures, livelihoods, as well as their physical and supernatural well-being. The Orang Asli community have a low quality of life as a consequence of being entirely reliant on traditional socioeconomic resources (Abdullah et al., 2019). These rural socio-economic activities lead them to live in isolated and countryside areas that are near their food resources. The Orang Asli community are entirely reliant on forest yields to live 
which are their regular socio-economic activity, but this places them in a precarious position as they cannot fit into the mainstream chain of events that churn productivity (Kamaruddin \& Jusoh, 2008). Ancient ancestral tradition and culture are the major factors that hamper their initiative to make changes and adapt to a more progressive and developed environment. They still believe in the forest and natural environment as a provider for their livelihood (Abdullah et al., 2019). Generally, the Orang Asli populations in Malaysia are very poor compared to the mainstream races even though there are various initiatives done by the Government of Malaysia (GoM) to integrate the Orang Asli with the mainstream races (Department of Orang Asli Affairs, 2008). According to $10^{\text {th }}$ Malaysia Plan (2011-2015), the Orang Asli in Malaysia still lives in poor conditions and have a low quality of life. However, there are many anti-poverty programs have been implemented to uplift their socioeconomic status (Malaysia's Prime Minister's Department, 2010).

The acceleration of economic development has converted the forests into plantations, mines, residential and land development. The Orang Asli lands now are covered by major construction such as roads and dams that destroyed vast tracts of forest land, as well as their livelihoods. Moreover, logging activities has become an important export which bankrolling Malaysia's development besides palm oil plantation, which boosts up the land degradation. In Terengganu the Orang Asli were moved out from their original village to the new settlement which built up by the government at the suburbs areas because of the extension of palm oil plantation and Kenyir damn. Even though they were moved to resettlement villages where all of the necessary amenities and facilities are provided but still they are relying on forest yields to survive (Abdullah et al., 2016). Ironically, these are threats that extinguish both traditional knowledge of Orang Asli and the surrounding biodiversity, which have been their forest homelands for decades. Traditional knowledge, heritage, and culture of Orang Asli have deteriorated due to the rapid urbanisation and rapid loss of forest area. In addition, some other threats that have much impact are assimilation into mainstream society or their adoption of a different worldview (Lee, Chang \& Noraswati, 2009). 


\section{Methodology}

This is exploratory research carried out at three Orang Asli resettlement villages in three different districts in the state of Terengganu, Malaysia (East Coast of Peninsular Malaysia). The focus of this study is to document the utilisation of natural resources based on Orang Asli knowledge who live there (Figure 1).

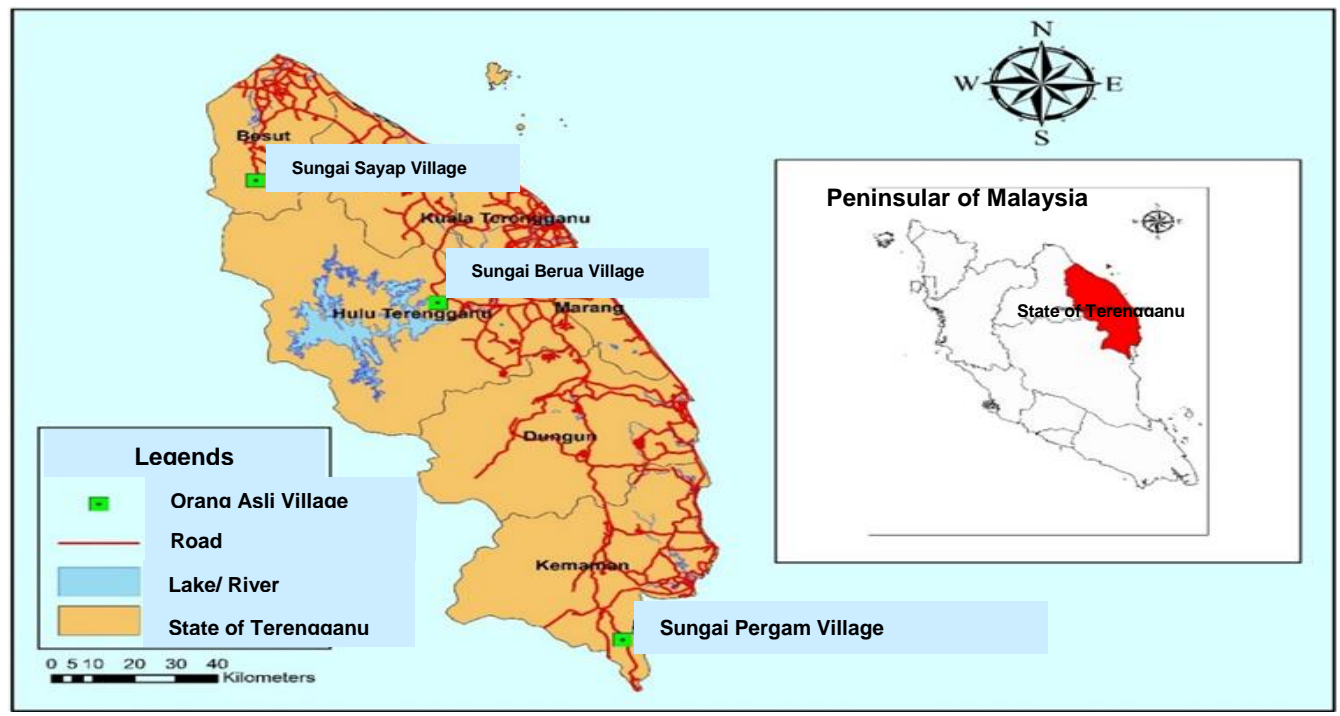

Figure 1: The location of Orang Asli village

(Source: Muhammad Fuad Abdullah.)

This study managed to get 11 informants from the research fieldwork. A qualitative approach was employed in this case study in which data was collected through in-depth interviews and field observations. This study was carried out among the Semaq Beri and Bateq tribes in Sungai Berua village in the district of Hulu Terengganu, Sungai Pergam village in the district of Kemaman and Sungai Sayap village in the district of Besut. Table 1 shows that the total population of three villages was 1326 including 182 head of household (Abdullah et al., 2016).

Table 1: Distribution of Orang Asli in Terengganu

\begin{tabular}{|l|l|l|c|c|}
\hline \multicolumn{1}{|c|}{ District } & \multicolumn{1}{|c|}{ Village } & $\begin{array}{c}\text { Orang Asli } \\
\text { Sub-tribe }\end{array}$ & $\begin{array}{c}\text { Head of } \\
\text { Household (HoH) }\end{array}$ & Population \\
\hline Kemaman & Sungai Pergam & Semaq Beri & 8 & 683 \\
\hline Hulu Terengganu & Sungai Berua & Semaq Beri & 95 & 605 \\
\hline Besut & Sungai Sayap & Bateq & 140 & 38 \\
\hline \multicolumn{2}{|l|}{ Total } & 182 & 1326 \\
\hline
\end{tabular}

Source: Abdullah et al. (2016). 


\section{Analysis}

The interview began with a brief introduction of the researcher team. The purpose of this action is to gain trust and build a good relationship between researcher and villagers, especially the elderly. Thus, they give the information freely and openly as outlined without any barrier. Focus group discussion approach was used to gather the information about the Orang Asli traditional knowledge on the type of flora and fauna available in particular areas as well as their uses. The selection of the informants was made before based on the purposive sampling technique, and interview protocol was developed as the interview instrument. To gather more information from about the informants, the snowball sampling technique was used to carry out the preliminary study. The sampling technique requires informant to suggest the others who may become the informant from whom information regarding the traditional knowledge about using natural resources can be collected.

Furthermore, the informant should be the head of the household with age must be over 30 years old. They were selected to be interviewed as they are the most knowledgeable about the utilisation of natural resources. They were questioned individually by a set of semi-structured interviews with the assistance of the Department of Orang Asli Affairs' officer and the headman (Tok Batin). In addition, it is easier for the researcher to get precise information and verify the fact instantly with the existence of local authorities because some of the informants used the Orang Asli language and their accent to give the required information besides the Malay language where it is used as an intermediate language. The collected data was analysed by referring to the International Union for Conservation of Nature (IUCN) and Malaysia Biodiversity Information System (MyBIS) for the accurate list.

\section{Findings and Discussions}

The movement of Semaq Beri and Bateq to the new settlement areas seems does not give any changes to their socioeconomic activities. They still have to collect forest yields to survive. There are a few factors that contribute, including 1 . the location of the resettlements, which is the location in the suburbs where it is still surrounded by forest and quite far from nearby town; 2. Most of the Orang Asli do not have the good qualifications that qualified the nearby industry; 3 . The Orang Asli does not have skills that meet the market; 4 . Most of them have better skills in forest works. Therefore, the forest is the best solution to feed their families. They have utilised various natural resources for their survival, cash, and traditional medicinal practices. In this study, the data revealed the Semaq Beri and 
Bateq tribes are still relying on natural resources as their primary economic purposes of consuming, and medical practices. They usually use the oldfashioned method to gain and catch the forest yield needed. For instance, they are still using axe and cleaver for harvesting plants. For hunting activities, there were various methods used to hunt for specific wildlife, e.g. bamboo blowpipe to hunt for birds, deer and squirrel. Snare method is used to capture mousedeer, partridge and porcupine. Spear gun is used to capture medium-sized wildlife such as wild boar and trap to capture civet, mousedeer and porcupine. They also used various old techniques to capture aquatic wildlife for example, bare hand, diving, archery, fishing road and hook, nets, and bamboo trap.

\section{Plants and Herbs}

\section{Agarwood}

Agarwood or aloeswood, and else known as gaharu in the vernacular name, is one of the natural resources collected by the Orang Asli in Terengganu for their cash purpose. Agarwood is aggressively harvested in the forest for its fragrant resinous heartwood that usually derived from the timber of the genus Aquilaria malaccensis Lam (Thymelaeaceae). The latex obtained from this plant through inducement processes can be used to cure the injury, cutting, pest or insect disturbance, microorganism, fire, chemical, or colonisation. The strong scent of agarwood latex is highly favoured as perfumery, while the agarwood powder is used in incense and medicinal practices (Naef, 2011). The high demands from the global market mainly from the Middle East leads to lucrative prices of this plant. Therefore, the Orang Asli in Terengganu who live nearby forest working on agarwood as a part of their survival economic activity.

\section{Rattan}

The word rattan is derived from the Orang Asli and Malay 'rotan', the local name for climbing palm. The development of extensive Orang Asli and local community classification systems for rattans often reflects the social significance of rattan, and these taxonomies have developed to reflect rattan growth and usage in the forest. Generally, the rattan grows in moist areas and will be decreased in number when the area is experiencing a change in humidity. The Orang Asli mentioned that there are 13 species of rattans recorded found all over the nearby forest (Table 2). However, only a few of them are taken because of its specific usage and its market value. The most essential product of rattan palm is cane; this is a rattan stem stripped of its leaf sheaths. This stem is solid, strong, and uniform, yet is highly flexible. The range of indigenous uses of rattan canes is vast, from bridges to baskets, from fish traps to furniture, from crossbow string 
to yam ties (Dransfield, 2002). This plant has multipurpose usage for the Orang Asli, especially to build the house, basket, hunting equipment, trap, and accessories; besides it is also economically useful. High demand of certain species from the mainstream has led the Orang Asli to harvest rattans more aggressively for their survival. The rattan cane is extensively used across their range by local communities and play an important role in subsistence strategies for many rural populations. In the mainstream, rattans are very useful for processing furniture and handicrafts. There are only two species of rattans that have a very high market value which are known as Calamus manan (Manau) and Calamus Caesius (Sega) (Forestry Department Peninsular Malaysia, 2016). Around $20 \%$ of the known rattan species are of any commercial value while the remaining species are not being utilised due to flexibility and being prone to breakage or possessing, other poor mechanical properties, or due to biological rarity (Dransfield, 2002).

Table 2: Rattan used by the Orang Asli in Terengganu

\begin{tabular}{|c|l|l|l|}
\hline \multirow{4}{*}{ Family } & \multicolumn{1}{|c|}{ Scientific Name } & **Native Name & \multicolumn{1}{c|}{ Local Name } \\
\hline \multirow{5}{*}{} & Calamus balingensis Furtado & Tanah & Rotan tanah \\
\cline { 2 - 4 } & Calamus caesius Blume & Sega & Rotan sega \\
\cline { 2 - 4 } & Calamus conirostris Becc. & Kerai & Rotan kerai \\
\cline { 2 - 4 } & Calamus insignis Griff. & Batu & Rotan batu \\
\cline { 2 - 5 } & Calamus laevigatus Mart. & Riau/Tunggal & Rotan tunggal \\
\cline { 2 - 5 } & Calamus manan Miq. & Manau & Rotan manau \\
\cline { 2 - 5 } & Calamus polystachys Becc. & Sabong & Rotan sabong \\
\cline { 2 - 5 } & Calamus scipionum Lour. & Semambu & Rotan semambu \\
\cline { 2 - 5 } & Calamus sedens J.Dransf. & Duduk & Rotan duduk \\
\cline { 2 - 5 } & Calamus angustifolius Griff. & Tawau & Rotan tawau \\
\cline { 2 - 5 } & Calamus calicarpusGriff. & Jernang & Rotan jernang \\
\cline { 2 - 5 } & Korthalsia laciniosa (Griff.) Mart. & Udang & Rotan dahan \\
\cline { 2 - 5 } & $\begin{array}{l}\text { Plectocomia elongata Mart. ex } \\
\text { Blume }\end{array}$ & Matang & Rotan mantang \\
\hline
\end{tabular}

**Native name among Semaq Beri and Bateq tribes

This study also found that Semaq Beri and Bateq tribe in Terengganu also relied on herbs for their traditional medicinal practices and cash. Most of these species naturally grow in the forests, and are a crucial part in the traditional medicine of the Orang Asli. Majority of the species reported in this paper are widely known throughout Peninsular Malaysia and used in different medical conditions (Ong, 
Mat Zuki, \& Milow, 2011). The binomial and family names, native names, ailment treated and parts used are shown in Table 3. These 106 species of medicinal use are related to 55 families. The plants were often used by most of the informants more or less for the same purpose and with only slight variations in methods.

Table 3: The list of herbs used by the Orang Asli in Terengganu

\begin{tabular}{|c|c|c|c|c|}
\hline Family & Scientific Name & ${ }^{* *}$ Native Name & Ailment Treated & Parts Used \\
\hline \multirow[t]{3}{*}{ Acanthaceae } & $\begin{array}{l}\text { Andrographis } \\
\text { paniculata (Burm. F.) } \\
\text { Wall. Ex Nees }\end{array}$ & Hempedu Bumi & Hypertension, fever, diabetes & Whole plant \\
\hline & $\begin{array}{l}\text { Asystasia } \\
\text { coromandeliana Nees }\end{array}$ & Rumput Israel & $\begin{array}{l}\text { Constipation, swellings, cuts, } \\
\text { wounds, muscle cramps }\end{array}$ & Leaves \\
\hline & $\begin{array}{l}\text { Justicia gendarussa } \\
\text { Burm. f. }\end{array}$ & $\begin{array}{l}\text { Gandarusa } \\
\text { hitam }\end{array}$ & $\begin{array}{l}\text { Flatulence, post-partum, } \\
\text { coughs, thrush }\end{array}$ & $\begin{array}{l}\text { Leaves, } \\
\text { roots }\end{array}$ \\
\hline \multirow[t]{2}{*}{ Amaryllidaceae } & Allium cepa $\mathrm{L}$. & Bawang merah & Fever, flatulence, & Bulb \\
\hline & Allium sativum L. & Bawang putih & Flatulence & Bulb \\
\hline \multirow[t]{3}{*}{ Annonaceae } & Annona muricata L. & Durian belanda & $\begin{array}{l}\text { Head lice, nightmares, sore } \\
\text { throat, back pain, joint aches, } \\
\text { infertility, post-partum, } \\
\text { diabetes, hypertension, } \\
\text { intestinal parasites }\end{array}$ & $\begin{array}{l}\text { Leaves, } \\
\text { bark, fruits, } \\
\text { seeds }\end{array}$ \\
\hline & $\begin{array}{l}\text { Goniothalamus } \\
\text { macrophyllus }\end{array}$ & Tongkat Ali & Inner energy for men & Root \\
\hline & Polyalthia bullata King & Tongkat ali batu & Inner energy for men & Root \\
\hline Apiaceae & $\begin{array}{l}\text { Centella asiatica (L.) } \\
\text { Urban }\end{array}$ & Pegaga & $\begin{array}{l}\text { Ageing, cuts, sores, skin } \\
\text { diseases, leucorrhea, post- } \\
\text { partum, headache, } \\
\text { hypertension, lip cracks }\end{array}$ & Whole plant \\
\hline Apocynaceae & $\begin{array}{l}\text { Parameria laevigata } \\
\text { (Blume) K. Schum. }\end{array}$ & Akar putih & Body aches & Roots \\
\hline \multirow[t]{2}{*}{ Arecaceae } & Areca catechu L. & Pinang & Fever & Fruit \\
\hline & Iguanura sp. & Pokok kura-kura & Malaria & Leaves \\
\hline \multirow[t]{2}{*}{ Aristolochiaceae } & $\begin{array}{l}\text { Thottea grandiflora } \\
\text { Rottb. }\end{array}$ & Perdu beruang & Asthma & Roots \\
\hline & $\begin{array}{l}\text { Thottea grandiflora } \\
\text { Rottb. }\end{array}$ & $\begin{array}{l}\text { Hempedu } \\
\text { beruang }\end{array}$ & Cough & Root \\
\hline \multirow[t]{2}{*}{ Asparagaceae } & $\begin{array}{l}\text { Peliosanthes lurida } \\
\text { Ridl. }\end{array}$ & Lemba seratus & Flatulence & Roots \\
\hline & $\begin{array}{l}\text { Peliosanthes violacea } \\
\text { Wall }\end{array}$ & Rambu suntum & Veins aches & Roots \\
\hline \multirow[t]{2}{*}{ Asteraceae } & $\begin{array}{l}\text { Chromolaena odorata } \\
\text { (L.) R.M. King \& H. } \\
\text { Rob. }\end{array}$ & Kapal terbang & Cuts, wounds & Leaves \\
\hline & $\begin{array}{l}\text { Gynura procumbens } \\
\text { (Lour.) Merr. }\end{array}$ & Bayam cina & Diabetes, hypertension & Leaves \\
\hline
\end{tabular}


Traditional Knowledge and the Uses of Natural Resources by the Resettlement Indigenous People in Malaysia

\begin{tabular}{|c|c|c|c|c|}
\hline Balsaminaceae & Impatiens balsamina $\mathrm{L}$. & Keembung & Split nails, hypertension, & Leaves \\
\hline \multirow[t]{2}{*}{ Bignoniaceae } & $\begin{array}{l}\text { Oroxylum indicum (L.) } \\
\text { Kurz. }\end{array}$ & Pokok bekah & Family planning for women & Bark \\
\hline & $\begin{array}{l}\text { Stenochlaena palustris } \\
\text { (Burm.) Bedd. }\end{array}$ & Pucuk miding & Fever, shingles & $\begin{array}{l}\text { Young } \\
\text { leaves, stem }\end{array}$ \\
\hline Caricaceae & Carica papaya $\mathrm{L}$. & Betik & $\begin{array}{l}\text { Amenorrhea, fever, } \\
\text { hypertension, pimples, skin } \\
\text { blemish, cracks, constipation }\end{array}$ & $\begin{array}{l}\text { Leaves, } \\
\text { shoot, } \\
\text { flowers, sap } \\
\text { of fruit, ripe } \\
\text { fruit }\end{array}$ \\
\hline Commelinaceae & $\begin{array}{l}\text { Amischotolype } \\
\text { mollissima (Blume) } \\
\text { Hassk. }\end{array}$ & Tebu tikus & Hearing problem & Leaves \\
\hline Connaraceae & Cnestis palala Griff. & Asam jawa bukit & Diabetes & Roots \\
\hline Convolvulaceae & Ipomoea aquatica Fors. & Kangkung & Abscess & Leaves \\
\hline Crassulaceae & $\begin{array}{l}\text { Bryophyllum pinnatum } \\
\text { (L.) Pers. }\end{array}$ & $\begin{array}{l}\text { Setawar/ } \\
\text { Sedingin }\end{array}$ & $\begin{array}{l}\text { Headache, abscess, pus in ear, } \\
\text { skin itch }\end{array}$ & $\begin{array}{l}\text { Leaves, } \\
\text { roots }\end{array}$ \\
\hline Dilleniaceae & $\begin{array}{l}\text { Tetracera indica (Hout. } \\
\text { Ex Chris. \& Panz.) } \\
\text { Merr. }\end{array}$ & Mempelas & Skin itch, hypertension, fever & $\begin{array}{l}\text { Leaves, } \\
\text { roots }\end{array}$ \\
\hline Dioscoreacea & $\begin{array}{l}\text { Dioscorea orbiculata } \\
\text { Hook.f. }\end{array}$ & Ubi takop & Strength and energy & Tuber \\
\hline \multirow[t]{2}{*}{ Euphorbiaceae } & $\begin{array}{l}\text { Manihot esculenta } \\
\text { Crantz. }\end{array}$ & Ubi kayu & $\begin{array}{l}\text { Cuts, bites, stings, abscess, } \\
\text { fever, headache, influenza }\end{array}$ & $\begin{array}{l}\text { Leaves, } \\
\text { tuber }\end{array}$ \\
\hline & $\begin{array}{l}\text { Chrozophora } \\
\text { oblongifolia (Delile) } \\
\text { A.Juss. ex Spreng. } \\
\end{array}$ & Kayu padang & Fitness & Root \\
\hline \multirow[t]{4}{*}{ Fabaceae } & Senna tora $\mathrm{L}$. & Gelenggang seni & $\begin{array}{l}\text { Constipation, skin diseases, } \\
\text { heartburn, post-partum }\end{array}$ & $\begin{array}{l}\text { Shoot, } \\
\text { leaves, plant }\end{array}$ \\
\hline & Tamarindus indica L. & Asam jawa & $\begin{array}{l}\text { Fever, rough palm, swellings, } \\
\text { bites, stings, sore throat, } \\
\text { asthma, short of breath }\end{array}$ & Fruits, bark \\
\hline & Parkia speciosa Hassk. & Petai & Cough, diabetes, hypertension & $\begin{array}{l}\text { Leaves, } \\
\text { fruit, roots, }\end{array}$ \\
\hline & Mimosa pudica L. & Semalu & $\begin{array}{l}\text { Post-partum, athlete's foot, } \\
\text { swelling, }\end{array}$ & Whole plant \\
\hline Hypoxidaceae & $\begin{array}{l}\text { Molineria latifolia } \\
\text { (Dryand. ex } \\
\text { W.T.Aiton) Herb. ex } \\
\text { Kurz } \\
\end{array}$ & Nyior lembe & $\begin{array}{l}\text { Cuts, swellings, coughs, no } \\
\text { appetite }\end{array}$ & $\begin{array}{l}\text { Leaves, } \\
\text { rhizome }\end{array}$ \\
\hline \multirow[t]{4}{*}{ Lamiaceae } & $\begin{array}{l}\text { Plectranthus } \\
\text { scutellarioides (L.) R.Br }\end{array}$ & Ati-ati & $\begin{array}{l}\text { Stomach ache, flatulence, cuts, } \\
\text { sores, bites, stings, expel } \\
\text { placenta, post-partum, stop } \\
\text { lactation }\end{array}$ & Leaves \\
\hline & Hyptis brevipes Poit. & Setulang & Swollen joints & Leaves \\
\hline & $\begin{array}{l}\text { Orthosiphon aristatus } \\
\text { (Blume) Miq. }\end{array}$ & Misai kucing & $\begin{array}{l}\text { Sore throat, painful urination, } \\
\text { diabetes, headache, } \\
\text { hypertension }\end{array}$ & $\begin{array}{l}\text { Leaves, } \\
\text { flower, roots }\end{array}$ \\
\hline & Vitex longisepala King & Merian & Love potion & Root \\
\hline
\end{tabular}


Muhammad Fuad Abdullah, Azmah Othman, Rohana Jani, Candyrilla Vera Bartholomew, Elizabeth Pesiu $\mathcal{E}^{\mathrm{S}}$ Mohd Tajuddin Abdullah

\begin{tabular}{|c|c|c|c|c|}
\hline & \& Gamble & & & \\
\hline \multirow[t]{4}{*}{ Lauraceae } & $\begin{array}{l}\text { Cananga odorata } \\
\text { (Lamk.) Hk. f. \& Thom }\end{array}$ & Kenanga & $\begin{array}{l}\text { Body odor, scalp odor, skin } \\
\text { odor, skin itch }\end{array}$ & Bark \\
\hline & $\begin{array}{l}\text { Cinnamomum } \\
\text { cuspidatum }\end{array}$ & Rempah gunung & Energy & Root \\
\hline & Cinnamomum sp. & Kencing manis & Diabetes & Root \\
\hline & $\begin{array}{l}\text { Cinnamomum cinereum } \\
\text { Gamble. }\end{array}$ & Tajalawang & Flatulence & Whole plant \\
\hline Lecythidaceae & $\begin{array}{l}\text { Barringtonia } \\
\text { acutangula (L.) Gaertn. }\end{array}$ & Gajah beranak & Blood circulation & Roots \\
\hline Loganiacea & $\begin{array}{l}\text { Strychnos pubescens } \\
\text { C.B. Clarke }\end{array}$ & Tarik gajah & Ticks problem & Leaves \\
\hline Loranthaceae & $\begin{array}{l}\text { Macrosolen } \\
\text { cochinchinensis (Lour.) } \\
\text { Tiegh. }\end{array}$ & Dedalu api & Diarrhoea & Stem \\
\hline Lythraceae & Lawsonia inermis (L.) & Inai & $\begin{array}{l}\text { Jaundice neonatal, dandruff, } \\
\text { athlete's foot, weak nails, scar, } \\
\text { post-partum, facial condition }\end{array}$ & $\begin{array}{l}\text { Leaves, } \\
\text { roots }\end{array}$ \\
\hline \multirow[t]{3}{*}{ Malvaceae } & $\begin{array}{l}\text { Durio zibethinus } \\
\text { Murray }\end{array}$ & Durian & Influenza fever & Leaves \\
\hline & $\begin{array}{l}\text { Hibiscus rosa-sinensis } \\
\text { L. }\end{array}$ & $\begin{array}{l}\text { Bunga raya } \\
\text { putih }\end{array}$ & Fever, dry hair, cuts, sores & $\begin{array}{l}\text { Leaves, } \\
\text { roots }\end{array}$ \\
\hline & Urena lobata $\mathrm{L}$. & Pulut-pulut & Post-partum & Roots \\
\hline \multirow[t]{2}{*}{ Melastomataceae } & $\begin{array}{l}\text { Melastoma } \\
\text { malabathricum L. }\end{array}$ & Senduduk & $\begin{array}{l}\text { Cuts, diarrhea, leucorrhea, } \\
\text { tougue pain, travel sickness, } \\
\text { pot-partum }\end{array}$ & $\begin{array}{l}\text { Leaves, } \\
\text { fruit, roots, }\end{array}$ \\
\hline & $\begin{array}{l}\text { Neodissochaeta gracilis } \\
\text { (Jack.) Bakh. }\end{array}$ & Cetliot & Influenza fever & Leaves \\
\hline Meliaceae & $\begin{array}{l}\text { Dysoxylum alliaceum } \\
\text { Seem }\end{array}$ & Hatap selaya & Post-partum & Roots \\
\hline Menispermaceae & $\begin{array}{l}\text { Fibraurea tinctoria } \\
\text { Lour. }\end{array}$ & Pokok kuning & Jaundice & Roots \\
\hline Moraceae & Ficus deltoidea Jack & Mas Cotek & $\begin{array}{l}\text { Water in lungs, hypertension, } \\
\text { post-partum }\end{array}$ & Leaves \\
\hline Musaceae & Musa sapientum $\mathrm{L}$. & Pisang kebatu & Scalds & Fruits \\
\hline \multirow[t]{2}{*}{ Myrsinaceae } & $\begin{array}{l}\text { Mapania cuspidata } \\
\text { (Miq.) Uittien }\end{array}$ & Kacip fatimah ii & Women's fertility & Root \\
\hline & Mapermia custridata & Rumput reluh & Asthma & Root \\
\hline Myrtaceae & Psidium guajava L. & Jambu batu & Body odor, pimples, diarrhoea & Leaves, bark \\
\hline Olacaceae & $\begin{array}{l}\text { Scorodocarpus } \\
\text { borneensis Becc. }\end{array}$ & Kulim & Haemorrhoids & Roots \\
\hline Ophioglossaceae & $\begin{array}{l}\text { Helminthostachys } \\
\text { zeylanica (L.) \& Hook. }\end{array}$ & Tunjuk langit & Post-partum & Whole plant \\
\hline Oxalidaceae & Averrhoa bilimbi L. & Belimbing buluh & $\begin{array}{l}\text { Stomach ache, skin cracks, } \\
\text { coughs, goitre diabetes, } \\
\text { hypertension, pimples, skin } \\
\text { diseases, }\end{array}$ & $\begin{array}{l}\text { Leaves, } \\
\text { flowers } \\
\text { fruits, bark }\end{array}$ \\
\hline Pandanaceae & Freycinetia javanica & Kelawit mantai & Back pain & Roots \\
\hline
\end{tabular}




\begin{tabular}{|c|c|c|c|c|}
\hline & \multicolumn{4}{|l|}{ Blume. } \\
\hline & $\begin{array}{l}\text { Pandanus } \\
\text { amaryllifolius Roxb. }\end{array}$ & Pandan & Vaginal itch, post-partum & Leaves \\
\hline \multirow[t]{3}{*}{ Phyllanthaceae } & $\begin{array}{l}\text { Phyllanthus acidus (L.) } \\
\text { Skeels. }\end{array}$ & Cermai & $\begin{array}{l}\text { Diabetes, hypertension, } \\
\text { pimples }\end{array}$ & Leaves \\
\hline & Phyllanthus niruri $\mathrm{L}$. & Dukung anak & $\begin{array}{l}\text { Diabetes, hypertension, pain } \\
\text { during menses, jaundice, } \\
\text { cough, sores }\end{array}$ & Plant, leaves \\
\hline & $\begin{array}{l}\text { Sauropus androgynus } \\
\text { (L.) Merr }\end{array}$ & Cekok manis & Hair growth, hypertension, & Leaves \\
\hline \multirow[t]{2}{*}{ Piperaceae } & Piper betle $\mathrm{L}$. & Sireh & $\begin{array}{l}\text { Nosebleed, toothache, sores, } \\
\text { abscess, fever, vaginal itch, } \\
\text { flatulence, poor eyesight, bad } \\
\text { breath }\end{array}$ & Leaves \\
\hline & $\begin{array}{l}\text { Piper sarmentosum } \\
\text { Roxb. }\end{array}$ & Kadok & $\begin{array}{l}\text { Malarial fever, diabetes, } \\
\text { difficult urination }\end{array}$ & $\begin{array}{l}\text { Leaves, } \\
\text { roots }\end{array}$ \\
\hline \multirow[t]{4}{*}{ Poaceae } & $\begin{array}{l}\text { Lophatherum gracile } \\
\text { Brongn }\end{array}$ & Cekrek & Hypertension & Roots \\
\hline & $\begin{array}{l}\text { Cymbopogon citratus } \\
\text { (DC) Stapf }\end{array}$ & Serai & $\begin{array}{l}\text { Hair loss, mosquito repellent, } \\
\text { difficult urination, fever }\end{array}$ & Whole plant \\
\hline & $\begin{array}{l}\text { Cymbopogon } \\
\text { winterianus Jowitt ex } \\
\text { Bor. }\end{array}$ & Serai wangi & $\begin{array}{l}\text { Stomachache, swellings, } \\
\text { painful menstruation }\end{array}$ & Whole plant \\
\hline & $\begin{array}{l}\text { Imperata cylindrica (L.) } \\
\text { Raeusch. \& P.Beauv. }\end{array}$ & Lalang & $\begin{array}{l}\text { Fever, asthma, short of breath, } \\
\text { difficult urination, urinary } \\
\text { stones }\end{array}$ & Rhizome \\
\hline Polypodiaceae & $\begin{array}{l}\text { Pyrossia piloselloides } \\
\text { (L.) M.G.Price. }\end{array}$ & Duit-duit & Headache, skin itch & Leaves \\
\hline \multirow[t]{2}{*}{ Polyporaceae } & $\begin{array}{l}\text { Lignosus rhinocerus } \\
\text { (Cooke) Ryvarden }\end{array}$ & Susu rimau & $\begin{array}{l}\text { Asthma, increase energy, } \\
\text { breast cancer, body aches }\end{array}$ & Tuber \\
\hline & $\begin{array}{l}\text { Talinum fruticosum } \\
\text { (L.) Juss.. }\end{array}$ & Pokok duit RM5 & Abscess, sores & Leaves \\
\hline Primulaceae & Ardisia sp. & Kayu membuluh & Ulcer & Root \\
\hline \multirow[t]{8}{*}{ Rutaceae } & Ixora sp. & Pokok pengeras & Men mystic & Root \\
\hline & Labisia pumila & Kacip fatimah i & Women's fertility & Root \\
\hline & Prismatomeris sp. & Haji samad & High blood pressure & Root \\
\hline & $\begin{array}{l}\text { Spermacoce articularis } \\
\text { L.f }\end{array}$ & Susu Kambing & Joint aches, muscle pain & Whole plant \\
\hline & $\begin{array}{l}\text { Jasminum sambac (L.) } \\
\text { Aiton. }\end{array}$ & Melor & $\begin{array}{l}\text { Food poisoning, fever, } \\
\text { measles, pimples, skin } \\
\text { infections, leucorrhoea, } \\
\text { painful menstruation }\end{array}$ & $\begin{array}{l}\text { Leaves, } \\
\text { Flower bud, } \\
\text { Roots }\end{array}$ \\
\hline & $\begin{array}{l}\text { Mitragyna speciosa } \\
\text { (Korth.) Havil }\end{array}$ & Ketum & Headache & Leaves \\
\hline & $\begin{array}{l}\text { Morinda corneri K. M. } \\
\text { Wong }\end{array}$ & $\begin{array}{l}\text { Mengkudu } \\
\text { hutan }\end{array}$ & $\begin{array}{l}\text { Post-partum, hypertension, } \\
\text { difficult urination }\end{array}$ & $\begin{array}{l}\text { Leaves, } \\
\text { fruit, roots }\end{array}$ \\
\hline & $\begin{array}{l}\text { Timonius wallichianus } \\
\text { (Korth.) Val. }\end{array}$ & $\begin{array}{l}\text { Patah bawah } \\
\text { tangga }\end{array}$ & Low sexual energy for man & Roots \\
\hline
\end{tabular}


Muhammad Fuad Abdullah, Azmah Othman, Rohana Jani, Candyrilla Vera Bartholomew, Elizabeth Pesiu ${ }^{5} \&$ Mohd Tajuddin Abdullah

\begin{tabular}{|c|c|c|c|c|}
\hline & $\begin{array}{l}\text { Murraya koenigii (L.) } \\
\text { Spreng. }\end{array}$ & Pokok kari & Hemafecia & Roots \\
\hline \multirow[t]{2}{*}{ Sapindaceae } & $\begin{array}{l}\text { Guioa pubescens (Zoll. } \\
\text { \& Mor.) Radlk. }\end{array}$ & Cemenui & Influenza fever, headache & $\begin{array}{l}\text { Leaves, } \\
\text { roots }\end{array}$ \\
\hline & $\begin{array}{l}\text { Nephelium lappaceum } \\
\text { L. }\end{array}$ & Rambutan & Vomit & Leaves \\
\hline \multirow[t]{2}{*}{ Smilacaceae } & $\begin{array}{l}\text { Smilax myosotiflora } \\
\text { A.DC. }\end{array}$ & Ubi jaga & Strength, energy & Root \\
\hline & $\begin{array}{l}\text { Smilax calophylla Wall. } \\
\text { ex A.DC. }\end{array}$ & Alek tembaga & Low sexual energy for man & Roots \\
\hline Solanaceae & Solanum torvum Sw. & Terung pipit & $\begin{array}{l}\text { Cuts, toothache, } \\
\text { Hypertension, headache, } \\
\text { urinary stones, skin cracks }\end{array}$ & $\begin{array}{l}\text { Leaves, } \\
\text { fruits, roots }\end{array}$ \\
\hline Tectariaceae & $\begin{array}{l}\text { Tectaria angulata } \\
\text { (Willd.) Copel. }\end{array}$ & Paku bukit & Asthma & Roots \\
\hline \multirow[t]{5}{*}{ Vitaceae } & $\begin{array}{l}\text { Ampelocissus gracilis } \\
\text { (Wall.) Planch. }\end{array}$ & Kertas api & Large sores & Leaves \\
\hline & Cissus repens Lam. & Ubi kertas & Haemorrhoids & Tuber \\
\hline & $\begin{array}{l}\text { Leea indica (Burm. f.) } \\
\text { Merr. }\end{array}$ & Kerak nasi & Diabetes & Leaves \\
\hline & $\begin{array}{l}\text { Alpinia galanga (L.) } \\
\text { Willd. }\end{array}$ & Lengkuas & $\begin{array}{l}\text { Skin diseases, Flatulence, } \\
\text { fever, post-partum }\end{array}$ & $\begin{array}{l}\text { Rhizome, } \\
\text { leaves, plant }\end{array}$ \\
\hline & $\begin{array}{l}\text { Cheilocostus speciosus } \\
\text { (J. Koenig) C.D. } \\
\text { Specht. }\end{array}$ & $\begin{array}{l}\text { Tepus bukit } \\
\text { (bunga putih) }\end{array}$ & Cuts, wounds & Stem \\
\hline Xanthorrhoeceae & Aloe vera (L.) Burm. f. & Lidah buaya & $\begin{array}{l}\text { Burns, fever, pimples, } \\
\text { dandruff }\end{array}$ & Leaves, sap \\
\hline \multirow[t]{7}{*}{ Zingiberaceae } & Curcuma longa L. & Panau & Tine vesicular & Leaves \\
\hline & Curcuma longa $\mathrm{L}$. & Kunyit & $\begin{array}{l}\text { Post-partum, aging, pimples, } \\
\text { sores, abrasions, ficial } \\
\text { dermatitis, difficulty breathing }\end{array}$ & Rhizome \\
\hline & $\begin{array}{l}\text { Curcuma viridiflora } \\
\text { Roxb. }\end{array}$ & Kunyit emas & Hemafecia, water in lungs & Rhizome \\
\hline & $\begin{array}{l}\text { Curcuma zanthorrhiza } \\
\text { Roxb. }\end{array}$ & Temulawak & Ageing & Roots \\
\hline & $\begin{array}{l}\text { Etlingera elatior (Jack) } \\
\text { R.M.Sm. }\end{array}$ & Kantan & Cuts, wounds, earache & $\begin{array}{l}\text { Leaves, } \\
\text { fruits }\end{array}$ \\
\hline & $\begin{array}{l}\text { Hedychium } \\
\text { longicornutum Griff. } \\
\text { ex Baker }\end{array}$ & $\begin{array}{l}\text { Ramu akar } \\
\text { cacing }\end{array}$ & Worms & Roots \\
\hline & $\begin{array}{l}\text { Zingiber officinale } \\
\text { Roscoe. }\end{array}$ & Halia & $\begin{array}{l}\text { Sprain, flatulence, bites, } \\
\text { menses pain, headache, weak } \\
\text { teeth, leucorrhoea, post- } \\
\text { partum }\end{array}$ & $\begin{array}{l}\text { Leaves, } \\
\text { rhizome }\end{array}$ \\
\hline
\end{tabular}

${ }^{* *}$ Native name among Semaq Beri and Bateq tribes 


\section{Animals}

Animals are also utilised as a food source, as pets, as remedies for traditional medicine and folktales by the Orang Asli in Terengganu. . Those animals are usually captured from the nearby forest (David et al., 2019). As such, hunting animals is not a prior activity for the Orang Asli to get some cash or as their main economic activity. Hunting is a side activity for Orang Asli in Terengganu whenever they go into the forest to get herbs and some other non-timber forest products. There are 31 different species of wild animals captured by the Semaq Beri and Bateq tribes. Most of them are mammals 13 species (42\%), reptiles 9 species (29\%) and aves 9 species (29\%) as are presented in (Table 4 ).

Table 4: The list of animals commonly captured by the Orang Asli in Terengganu

\begin{tabular}{|c|c|c|c|c|}
\hline Family & Scientific Name & ${ }^{* *}$ Native Name & Local Name & English Name \\
\hline \multicolumn{5}{|l|}{ Reptiles } \\
\hline Emydidae & Trachemys scripta & Kura merah & $\begin{array}{l}\text { Kura terlinga- } \\
\text { merah }\end{array}$ & Red-eared slider \\
\hline Gekkonidae & Gekko gecko & Che'eh & Cicak tokek & Tokay gecko \\
\hline \multirow[t]{4}{*}{ Geoemydidae } & Cuora amboinensis & Kura Batu & Kura katap & Malayan box turtle \\
\hline & Heosemys spinosa & Mong & $\begin{array}{l}\text { Kura-kura duri } \\
\text { bukit }\end{array}$ & Spiny hill turtle \\
\hline & $\begin{array}{l}\text { Siebenrockiella } \\
\text { crassicollis }\end{array}$ & Yo & $\begin{array}{l}\text { Kura-kura pipi- } \\
\text { putih }\end{array}$ & Black marsh turtle \\
\hline & Manouria emys & Sel & Baning perang & Asian brown turtle \\
\hline Pythonidae & Python reticulatus & Tijo & Ular sawa batik & Reticulated python \\
\hline Trionychidae & Dogania subplana & $\mathrm{Pa}^{\prime}$ as & Labi-labi hutan & Malayan softshell turtle \\
\hline Varanidae & Varanus salvator & Sereng & Biawak & Water monitor lizard \\
\hline \multicolumn{5}{|l|}{ Aves } \\
\hline \multirow[t]{2}{*}{ Becerotidae } & Rhinoplax vigil & Terang & Burung enggang & Helmeted hornbill \\
\hline & $\begin{array}{l}\text { Anthracoceros } \\
\text { albirostris }\end{array}$ & $\begin{array}{l}\text { Kawah } \\
\text { kelingking } \\
\end{array}$ & $\begin{array}{l}\text { Burung } \\
\text { kelingking } \\
\end{array}$ & Oriented pied hornbill \\
\hline Columbidae & Chalcophaps indica & Kawah kukur & Burung tekukur & Emerald dove \\
\hline \multirow[t]{2}{*}{ Phasianidae } & Gallus gallus & Ayam hutan & Ayam hutan & Junglefowl \\
\hline & Lophura ignite & Ayam pegar & Ayam pegar & Crested fireback \\
\hline Psittaculidae & Psittinus cyanurus & Kawah Serindit & Burung serindit & Blue-rumped parrot \\
\hline Pycnonotidae & $\begin{array}{l}\text { Pycnonotus } \\
\text { zeylanicus }\end{array}$ & Kawah Barau & Burung barau & Straw-headed bulbul \\
\hline Rallidae & $\begin{array}{l}\text { Amaurornis } \\
\text { phoenicurus }\end{array}$ & Itik air & Burung ruak & Waterhen \\
\hline Sturnidae & Gracula religiosa & Kawah Tiong & Burung tiong & Common hill myna \\
\hline
\end{tabular}


Muhammad Fuad Abdullah, Azmah Othman, Rohana Jani, Candyrilla Vera Bartholomew, Elizabeth Pesiu ${ }^{5} \&$ Mohd Tajuddin Abdullah

\begin{tabular}{|c|c|c|c|c|}
\hline \multirow[t]{2}{*}{$\begin{array}{l}\text { Cercopithecid } \\
\text { ae }\end{array}$} & Macaca nemestrina & Penrok & Beruk & $\begin{array}{l}\text { Southern pig-tailed } \\
\text { macaque }\end{array}$ \\
\hline & $\begin{array}{l}\text { Trachypithecus } \\
\text { obscurus }\end{array}$ & Basing & Ungka & Dusky leaf monkey \\
\hline \multirow[t]{2}{*}{ Cervidae } & Rusa unicolor & Rusa & Rusa & Sambar deer \\
\hline & Muntiacus muntjak & Bohol & Kijang & Barking deer \\
\hline Manidae & Manis javanica & Pantuai & Tenggiling & Sunda pangolin \\
\hline \multirow[t]{2}{*}{$\begin{array}{l}\text { Cercopithecid } \\
\text { ae }\end{array}$} & Macaca nemestrina & Penrok & Beruk & $\begin{array}{l}\text { Southern pig-tailed } \\
\text { macaque }\end{array}$ \\
\hline & $\begin{array}{l}\text { Trachypithecus } \\
\text { obscurus }\end{array}$ & Basing & Ungka & Dusky leaf monkey \\
\hline \multicolumn{5}{|l|}{ Mammals } \\
\hline \multirow[t]{2}{*}{$\begin{array}{l}\text { Cercopithecid } \\
\text { ae }\end{array}$} & Macaca nemestrina & Penrok & Beruk & $\begin{array}{l}\text { Southern pig-tailed } \\
\text { macaque }\end{array}$ \\
\hline & $\begin{array}{l}\text { Trachypithecus } \\
\text { obscurus }\end{array}$ & Basing & Ungka & Dusky leaf monkey \\
\hline \multirow[t]{2}{*}{ Cervidae } & Rusa unicolor & Rusa & Rusa & Sambar deer \\
\hline & Muntiacus muntjak & Bohol & Kijang & Barking deer \\
\hline Manidae & Manis javanica & Pantuai & Tenggiling & Sunda pangolin \\
\hline Hystricidae & Hystrix brachyura & Landak & Landak & Malayan porcupine \\
\hline \multirow[t]{2}{*}{ Sciuridae } & Callosciurus notatus & Lebir & Tupai plantain & Plantain squirrel \\
\hline & Ratufa bicolor & Daguan & Tupai jelarang & Black giant squirrel \\
\hline Spalacidae & $\begin{array}{l}\text { Rhizomys } \\
\text { sumatrensis }\end{array}$ & De'kan & Dekan & Indo-malayan bamboo rat \\
\hline Suidae & Sus scrofa & Jalu & Babi hutan & Wild pig \\
\hline Tragulidae & Tragulus napu & Pelanduk & Pelanduk & Mousedeer \\
\hline
\end{tabular}

** Native names among Semaq Beri and Bateq tribes

\section{Fish}

The findings show that the Orang Asli also utilised fish as their primary food source. All of the Orang Asli resettlement villages in Terengganu are located nearby stream. Fortunately, Kampung Sungai Berua, Kemaman has more advantage compared than others because it is situated nearby Kenyir Lake which is recognised as one of the largest human-made lakes in Southeast Asia and also placed inside of Terengganu state park. Thus, the Orang Asli in Terengganu has an abundant source of fish for their survival. There are 31 different species of fishes caught by the Orang Asli in Terengganu (Table 5). Most of them are used as food, and a few of them are used for medicine and cash purpose. There are 13 main species of fishes commonly captured by the Orang Asli. The most typical 
species are Cyprinidae (52\%) followed by Channidae (10\%) and Osphronomidae $(6 \%)$.

Table 5: The List of Aquatic Resources Taken by the Orang Asli in Terengganu

\begin{tabular}{|c|c|c|c|}
\hline Family & Scientific Name & **Native Name & Usage \\
\hline Anabantidae & Anabas testudineus & Puyu & Food \\
\hline Bagridae & Hemibagrus capitulum & Baung & Food \\
\hline \multirow[t]{3}{*}{ Channidae } & Channa Lucius & Bujuk & Food \\
\hline & Channa micropeltes & Toman & Food \\
\hline & Channa striata & Haruan & Food, Medicine \\
\hline Cichlidae & Tilapia sp. & Talapia Merah & Food \\
\hline Clariidae & Clarias microcephalus & Keli Bunga & Food \\
\hline \multirow[t]{16}{*}{ Cyprinidae } & Barbonymus schwanafeldi & Lampam Sungai & Food \\
\hline & Ctenopharyngodon idella & Kap Rumput & Food \\
\hline & Cyclocheilichthys apogon & Temperas & Food \\
\hline & Epalzeorhynchos kalopterus & Selimang/ Rong Batu & Food \\
\hline & Hampala macrolepidota & Sebarau & Food \\
\hline & Hypsibarbus malcolmi & Kerai & Food \\
\hline & Labiobarbus leptocheilus & Kawan & Food \\
\hline & Mystacoleucus marginatus & Sia & Food \\
\hline & Neolisocheilus soroides & Tengas & Food, Sale \\
\hline & Osteocheilus spilurus & Rong & Food, Sale \\
\hline & Osteochilus vittatus & Terbul & Food \\
\hline & Oxygaster anomalura & Lalang/ Parang/ Aur & Food \\
\hline & Probarbus jullieni & Temoleh & Food \\
\hline & Propontius deauratus & Daun & Food \\
\hline & Rasbora sp. & Seluang & Food \\
\hline & Tor tambra & Kelah & Food, Sale \\
\hline Eleotridae & Oxyeleotris marmorata & Ubi/ Ketutu & Food \\
\hline Notopteridae & Chitala lopis & Belida & Food \\
\hline \multirow[t]{2}{*}{ Osphronomidae } & Osphronemus goramy & Kalui & Food \\
\hline & Trichopodus trichopterus & Sepat & Food \\
\hline Osteoglossidae & Scleropages formosus & Kelisa & Food, sale \\
\hline Pangasiidae & Pangasius nasutus & Patin & Food \\
\hline Pristolepididae & Pristolepis fasciatus & Patung & Food \\
\hline Siluridae & Wallago leerii & Tapah & Food \\
\hline
\end{tabular}

**Native name among Semaq Beri and Bateq tribes

\section{Conclusion and Recommendations}

This study shows that even though the government is providing a lot of incentives to enhance the socioeconomic of Orang Asli community but the Semaq 
Beri and Bateq tribes in Terengganu are still relying on natural resources for their livelihood. They are practising their ancestral knowledge through traditional skills and methods for their survival. These methods are used in curing of diseases, farming and cultivating plants, fishing, house construction, making handicrafts and harvesting forest resources. Findings show that the Orang Asli in Terengganu commonly harvests two types of non-timber forest products, namely agarwood and rattan to make their cash earnings. In addition to it the Orang Asli often use 106 species of plants and herbs, 31 species of animals and 31 species of fishes in Terengganu.

Interestingly, this vulnerable group still applying the ancestral conventional practices and techniques to harvest the natural resources needed for their survival. However, the forest yields that they collect is not harvested in a large scale where it can put the species into the endangered or extinction level. The Orang Asli just utilise the forest for their survivals.

Due to rapid development and modernisation, most of the younger generations are lacking their traditional knowledge. It is of greater concern that some of the traditional knowledge is buried together with the old generation. Orang Asli traditional knowledge as well as the forest natural resources requires support from local government and authorities to take on preservation measures. This is possible through ethnographical, ethno-botanical, ethno-medical and zoological recordings. The preservation of these national treasures is an indispensable obligation for sustaining the traditional knowledge, natural resources and culture of the Orang Asli. Increasing the Orang Asli knowledge regarding the forest is not only favourable for their well-being and livelihood, but it can sustainably preserve their natural resources. Hence, the government and policymakers should give some attention to protect the traditional knowledge of the Orang Asli specifically among the younger generation, which is extremely exposed and affected to mainstream attractions lately. The education policies regarding Orang Asli should be following the Article 14 of the UN Declaration on the Right of Indigenous People (UNDRIP) where it promotes the recognition of the right of the Orang Asli to inaugurate their educational programmes by providing education in their languages in a manner appropriate to their culture of teaching and learning.

\section{Acknowledgements}

This study gratefully acknowledges the Ministry of Higher Education Malaysia for the fund through Transdisciplinary Research Grant Scheme (TRGS vote no. 59373). The authors appreciate the services and facilities provided by the Institute of Tropical Biodiversity and Sustainable Development, Universiti 
Malaysia Terengganu. Special thanks for the permission and cooperation of the village authorities and Department of Orang Asli Development (JAKOA).

\section{References}

Abdullah, M. F., Othman, A., Edo, J., \& Jani, R. (2019). Multidimensional poverty index of marginalized Orang Asli in Terengganu, Malaysia. Pertanika Journal of Social Sciences E Humanities, 27(2), 1241-1259.

Abdullah, M. F., Rohana, J., \& Abdullah, M. T. (2016). The sustainability of Orang Asli community in the mainstream. In M. T. Abdullah, M. F. Abdullah, C. V. Bartholomew, \& R. Jani (Eds.), The sustainability of Orang Asli in Terengganu (pp. 85-115). Kuala Terengganu: Universiti Malaysia Terengganu Press.

Anyaoku, E. N., Nwafor-Orizu, O. E., \& Eneh, E. A. (2015). Collection and preservation of traditional medical knowledge: Roles for medical libraries in Nigeria. Journal of Library and Information Sciences, 3(1), 33-43.

Campbell, Y. M., Ghazali, K., \& Suffian Sahuri, S. S. (2016). Preserving indigenous knowledge through folk narratives: Podi and Ngoyu. JATIJournal of Southeast Asian Studies, 21, 203-219.

Chan, C. S. C. (2018). Hegemony and agency in staged Mah Meri indigenous music and dance performances for tourist in Malaysia. JATI-Journal of Southeast Asian Studies, 23(1), 132-155.

Cheng, Y. X., Chong, C. P., Kiew, C. F., \& Bahari, M. B. (2014). An assessment of health and social-economic status among Lanoh ethnic sub-group of Orang Asli (Indigenous peoples) in Air Bah I Village, State of Perak, Malaysia. Journal of Applied Pharmaceutical Sciences, 4(10), 32-37.

Christen, K. (2015). Tribal archives, traditional knowledge, and local contexts: Why the "s" matters. Journal of Western Archives, 6(1), 1-19.

David, G., Roslan, A., Pesiu, E., \& Abdullah, M. T. (2019). A brief survey on the birds in Belukar Bukit, Kenyir, Terengganu Malaysia. In M. T. Abdullah, A. Mohammad, M. N. Zalipah, \& M. Lola (Eds.), Greater Kenyir landscapes: Social development and environmental sustainability: From ridge to reef (pp. 143-157). Cham: Springer Nature Switzerland.

Department of Orang Asli Affairs. (2008). The basis data of Department of Orang Asli Affairs. Kuala Lumpur: Nasional Printing of Malaysia Berhad.

Department of Orang Asli Affairs. (2011). The stategic planning of Orang Asli Development. Kuala Lumpur: Department of Orang Asli Affairs. 
Dransfield, J. (2002). General introduction to rattan: The biological background to exploitation and the history of rattan research. In J. Dransfield, F. O. Tesoro, \& N. Manokaran (Eds.), Rattan: Current research issues and prospects for conservation and sustainable development (pp. 23-34). Rome: Food and Agriculture Organization of the United Nations

Endicott, K., \& Dentan, R. K. (2004). Into the mainstream or into the backwater? In C. R. Duncan (Ed.), Civilising the margins: Southeast Asian government policies for the development of minorities (pp. 24-55). Ithaca: Cornell University Press.

Forestry Department Peninsular Malaysia. (2016). Rattan and bamboo. Retrieved from https://www.forestry.gov.my/index.php/my/buluh-dan-rotan

Friedlander, A. M., Wagner, D., Gaymer, C. F., Wilhelm, T. A., Lewis, N. A., Brooke, S., Kikiloi, K., \& Varmer, O. (2016). Co-operation between large-scale MPAs: Successful experiences from the Pacific Ocean. Aquatic Conservation: Marine and Freshwater Ecosystems, 26(2), 126-141.

Hussin, H. (2018). Branding Malaysia and re-positioning cultural heritage in tourism development. JATI-Journal of Southeast Asian Studies, Special Issue, 74-91.

International Work Group for Indigenous Affairs (IWGIA). (2017). The Indigenous world $2017 . \quad$ Retrieved from https://www.iwgia.org/images/documents/indigenousworld/indigenous-world-2017.pdf

Kalita, B., Choudhury, M., \& Ojha, S. N. (2004). Indigenous technical knowledge on pond construction and maintenance, fish seed transportation, and fish health management in Assam hills. Indian Journal of Traditional Knowledge, 3(2), 192-197.

Kamaruddin, K., \& Jusoh, O. (2008). Educational policy and opportunities of Orang Asli: A study on Indigenous people in Malaysia. Journal of Human Resource Adult Learn, 4(1), 86-97.

Kardooni, R., Kari, F. B., Yahaya, S. R. B., \& Yusup, S. H. (2014). Traditional knowledge of Orang Asli on forests in peninsular Malaysia. Indian Journal of Traditional Knowledge, 13(2), 238-291.

Lambin, R., Wahab, N. A., Choo, G. S., Mustapha, R., \& Abdullah, R. (2018). A case study of Orang Asli indigenous knowledge in traditional medicine. International Journal of Academic Research in Business and Social Sciences, 8(4), 998-1010.

Leake, H. (2007). Bridging the gap: Policies and practices on indigenous people' natural resources management in Asia. Chiang Mai: Unites Nations Development 
Programme-Regional Indigenous Peoples' Programme (UNDP-RIPP), AIPP Foundation.

Malaysia's Prime Minister's Department. (2010). 10th Malaysian plan 2011-2015. Retrieved from http://www.epu.gov.my/en/tenth-malaysia-plan-9th-mp-

Naef, R. (2011). The volatile and semi-volatile constituents of agarwood, the infected heartwood of Aquuilaria species: A review. Journal of Flavour and Fragrance, 26, 73-87.

Nor, H. M. (1991). Orang Asli and land ordinance: Preliminary study in Tapah, Perak. Akademika, 38(1), 105-120.

Ong, H. C., Mat Zuki, R., \& Milow, P. (2011). Traditional knowledge of medicinal plants among the Malay villagers in Kampung Mak Kemas, Terengganu, Malaysia. Journal of Ethno-med, 5(3), 175-185.

Organisation for Economic Co-operation and Development. (2001). The well-being of nations: The role of human and social capital. Paris: OECD Publications.

Permana, RCE. (1999). Konsep Kesejajaran Pria dan Wanita pada Masyarakat Baduy. Wacana, 1(1), Oktober 1999. 249-260.

Rosliza, A. M., \& Muhamad, J. J. (2011). Knowledge, attitude and practice on antenatal care among Orang Asli women in Jempol, Negeri Sembilan. Malaysian Journal of Public Health Medicine, 11(2), 13-21.

Ter Steege, H., Pitman, N. C., Killeen, T. J., Laurance, W. F., Peres, C. A., Guevara, J. E., ... \& De Souza, C. L. (2015). Estimating the global conservation status of more than 15,000 Amazonian tree, Species. Science Advances, 1(10), 1-10. doi:org/10.1126/sciadv.1500936.

Thevakumar, K., Chandren, J. R., Perez-Perez, G. I., Chua, E. G., The, L. K., Salleh, M. Z., ... \& Marshall, B. J. (2016). Assessment of risk and SeroPrevalence of Helicobacter pylori scolonisation among remote Orang Asli Tribes in Peninsula Malaysia. PloS one, 11(7), 1-15. doi.org/10.1371/journal.pone.0159830

United Nations. (2012). Urban Indigenous peoples and migration: Challenges and opportunities. Retrieved from http://www.un.org/esa/socdev/unpfii/documents/6_session_factsheet2.pd $\mathrm{f}$

World Bank. (2019). Indigenous people. Retrieved from https://www.worldbank.org/en/topic/indigenouspeoples 